\title{
1D to 3D NMR study of microporous alumino-phosphate $\mathrm{AlPO}_{4}-40$
}

\author{
Cláudia Morais $^{a, b}$, Valérie Montouillout ${ }^{a}$, Michael Deschamps $^{a}$, Dinu Iuga $^{a \dagger}$, \\ Franck Fayon ${ }^{a}$, Filipe A.A. Paz ${ }^{c}$, João Rocha ${ }^{c}$, Christian Fernandez ${ }^{d}$ and \\ Dominique Massiot ${ }^{f * a}$
}
a) CRMHT-CNRS (UPR4212 \& FR2950), 1D Ave Recherche Scientifique, 45071 Orléans cedex 2, France. Fax: +33 2386381 03; Tel: +33 2382555 18; E-mail: massiot@cnrs-orleans.fr
b) IREM (UMR8637) Université de Versailles Saint-Quentin-en-Yvelines, 45 Ave des Etats-Unis, 78035 Versailles France
c) Department of Chemistry, CICECO, University of Aveiro, 3810-192 Aveiro, Portugal.
d) LCS (UMR6506), ENSICAEN, 14050 Caen, France

\section{Short abstract ( $<200$ characters)}

We describe a new 3D ${ }^{27} \mathrm{Al}-{ }^{31} \mathrm{P}$ MQ-HMQC experiment and make use of oneto two- and three-dimensional MAS NMR solid state experiments to describe the complex structure of microporous alumino-phosphate $\mathrm{AIPO}_{4}-40$

\section{Abstract ( $<300$ words)}

From one- to two- and three-dimensional MAS NMR solid state experiments involving ${ }^{31} \mathrm{P}$ and ${ }^{27} \mathrm{Al}$ we show that the structure of microporous alumino-phosphate $\mathrm{AlPO}_{4}-40$ contains at least four times more sites than expected and we attribute two types of $\mathrm{Al}_{\mathrm{IV}}$ sites. The newly described ${ }^{27} \mathrm{Al}-{ }^{31} \mathrm{P}$ MQ-HMQC opens new possibilities in describing details of three dimensional bounded networks.

Keywords: NMR, 31P, 27Al, aluminophosphate, microporous materials

\section{Introduction}

Alumino-phosphate zeolitic or porous materials raise considerable interest for their properties as catalysts or molecular sieves. Because they involve abundant and sensitive nuclei $\left({ }^{27} \mathrm{Al},{ }^{31} \mathrm{P}\right)$ high resolution solid state NMR is a tool of choice for characterizing their local structure. Information obtained from high resolution solid state NMR can often be combined with diffraction results to examine complex structures with large unit cells and reach a comprehensive interpretation [1, 2]. High resolution solid state NMR provides different types of information. First, the spectral resolution provides a direct way for enumerating the non equivalent crystallographic sites occupied by the observed nuclei. Second, homo- or hetero-nuclear correlation experiments established using through space (dipolar) or through bond (indirect J-coupling) interactions, characterize the polyatomic structural motifs. In this contribution we examine the case of the microporous alumino-

\footnotetext{
${ }^{\dagger}$ Now at Lethbridge University, Canada

* To whom correspondence should be addressed massiot@cnrs-orleans.fr
} 
phosphate compound $\mathrm{AlPO}_{4}-40$ whose structure remains a matter of debate. We show that with NMR experiments conducted at high magnetic field $(750 \mathrm{MHz}-17.6 \mathrm{~T})$, it is possible to obtain improved spectral resolution by applying heteronuclear ${ }^{31} \mathrm{P}$ or ${ }^{27} \mathrm{Al}$ decoupling. These high resolution heteronuclear correlation experiments between ${ }^{31} \mathrm{P}$ and ${ }^{27} \mathrm{Al}$ or ${ }^{27} \mathrm{Al}$ and ${ }^{27} \mathrm{Al}$, show more than twenty different sites for each nucleus and provide their respective connectivity. From these results we show that the actual structure contains at least four times more sites than the proposed structure and, based on Al-Al correlation, we can also ascribe the two different types of $\mathrm{Al}_{\mathrm{IV}}$ environments to two of the sites of the proposed structure.

The AlPO4-40 sample is a microporous alumino-phosphate synthesized under hydrothermal conditions, using by tetrapropyl- and tetramethyl-ammonium templating cations [3]. The sample was kindly provided by Profs J. Lourenço \& M.F. Ribeiro (Portugal). Its structure was established from high resolution X-Ray diffraction [4] and involves height distinct four fold $\mathrm{P}(\mathrm{OAl})_{4}$ phosphorous sites and height distinct aluminium sites (6 four fold $\mathrm{Al}_{\mathrm{IV}}-\mathrm{Al}(\mathrm{OP})_{4}$ sites and 2 five fold $\mathrm{Al}_{\mathrm{V}}-\mathrm{Al}(\mathrm{OP})_{4} \mathrm{OH}$ sites $)$. However, as already demonstrated by several NMR studies, its structure appears to be much more complex, involving more than eight non-equivalent sites $[5,6]$.

\section{Experimental}

The high resolution solid state NMR experiments have been acquired on Bruker Avance 400 and $750 \mathrm{MHz}$ spectrometers using triple resonance MAS probeheads $(4 \mathrm{~mm}$ and $2.5 \mathrm{~mm})$. Each radiofrequency channel was equipped with band-pass filters. ${ }^{31} \mathrm{P}$ and ${ }^{27} \mathrm{Al}$ chemical shifts are reported in ppm relative to $85 \% \mathrm{H}_{3} \mathrm{PO}_{4}$ and $\mathrm{Al}\left(\mathrm{NO}_{3}\right)_{3} 1 \mathrm{M}$ solutions.

The ${ }^{31} \mathrm{P}\left\{{ }^{27} \mathrm{Al}\right.$ decoupled $\}$ MAS spectra of $\mathrm{AlPO}_{4}-40$ (Figure 1) were recorded on 400 and $750 \mathrm{MHz}$ spectrometers with MAS at $v_{\mathrm{r}}=14 \mathrm{kHz}$. Due to large $\mathrm{T}_{1}$ relaxation times $(>100 \mathrm{~s})$, ${ }^{31} \mathrm{P}$ MAS spectra have been acquired with pre-saturation (20 pulses of alternating phase $\mathrm{x}-\mathrm{y}$ spaced by a delay of $30 \mathrm{~ms}$ ) and recycle delays of $40 \mathrm{~s}$. Optimal resolution in the ${ }^{31} \mathrm{P}$ MAS spectrum was achieved using a ${ }^{27} \mathrm{Al}$ decoupling field of $12 \mathrm{kHz}$, however, no further resolution enhancement was obtained when using double resonance ${ }^{1} \mathrm{H} /{ }^{27} \mathrm{Al}$ decoupling.

\section{Results and discussion}

${ }^{31} \mathrm{P}$ MAS NMR spectra of $\mathrm{AlPO}_{4}-40$ are shown in Figure 1. Application of ${ }^{27} \mathrm{Al}$ decoupling during acquisition of the ${ }^{31} \mathrm{P}$ signal [6] leads to an important gain in resolution which is further enhanced by acquisition at higher field $(750 \mathrm{MHz})$. Because the $14 \mathrm{kHz}$ MAS spinning rate used is much larger than the heteronuclear dipolar couplings, the resolution enhancement obtained with heteronuclear decoupling is a direct evidence of the presence of an unresolved but significant isotropic J-coupling between ${ }^{31} \mathrm{P}$ and ${ }^{27} \mathrm{Al}$. The extra resolution obtained at high field $(750 \mathrm{MHz})$ further shows that the line broadening is not dominated by chemical shift distribution, as is often the case in inorganic solids. It is important to notice that even if the ${ }^{31} \mathrm{P}_{-}{ }^{27} \mathrm{Al} \mathrm{J}$-couplings remain small (in the order of 10 to $20 \mathrm{~Hz}$ ) each $\mathrm{P}$ is linked to 4 different $\mathrm{I}=5 / 2$ Al sites which give rise to a significant broadening (quadruplet of quintuplets with a $\mathrm{J}_{\mathrm{Al}-\mathrm{O}-\mathrm{P}}$ splitting) [6]. A good decomposition of the highest resolution spectrum involves a minimum of 21 different ${ }^{31} \mathrm{P}$ lines (Table 1).

The single-pulse ${ }^{27} \mathrm{Al}$ spectrum already shows some resolution at high field with a complete separation of $\mathrm{Al}_{\mathrm{IV}}$ and $\mathrm{Al}_{\mathrm{V}}$ domains and a partial resolution of two groups of $\mathrm{Al}_{\mathrm{IV}}$ resonances which was not observed at lower field due to the dominant second order quadrupolar broadening. The three $\mathrm{Al}_{\mathrm{IV}}-\mathrm{I} \mathrm{Al}_{\mathrm{IV}}-\mathrm{II}$ and $\mathrm{Al} \mathrm{V}_{\mathrm{V}}$ groups are in a 2:1:1 intensity ratio. Because second order quadrupolar effect is the dominant broadening mechanism, resolution enhancement is only observed in the isotropic dimension of the ${ }^{31} \mathrm{P}$ decoupled MQMAS experiment [12] (Figure 1) where second order broadening is cancelled out. The effect of 
heteronuclear decoupling is also of lesser importance for ${ }^{27} \mathrm{Al}$ nuclei because ${ }^{31} \mathrm{P}$ nuclei are $\mathrm{I}=1 / 2$ spins and thus the coupling of the observed ${ }^{27} \mathrm{Al}$ linked to four different $\mathrm{P}$ sites only give rise to quartet splitting, five times narrower than the J-broadening effect due to ${ }^{27} \mathrm{Al}$ in the ${ }^{31} \mathrm{P}$ spectrum. A crude first modeling of the MQMAS spectrum (Figure 2) would require more than 15 different ${ }^{27} \mathrm{Al}$ lines characterized by their isotropic chemical shifts and quadrupolar parameters. The high resolution MQMAS spectrum confirms the separation of the $\mathrm{Al}_{\text {IV }}$ resonances in two groups with isotropic chemical shifts ranging from 44 to $46 \mathrm{ppm}$ for $\mathrm{Al}_{\mathrm{IV}}-\mathrm{I}$ and 37 to $41 \mathrm{ppm}$ for $\mathrm{Al}_{\mathrm{IV}}-\mathrm{II}$ (while $\mathrm{Al}_{\mathrm{V}}$ are located between 19 and $23 \mathrm{ppm}$ ).

Enhanced resolution can be obtained by spreading the resonance lines in homo- or hetero-nuclear two dimensional correlation experiments. This proved to be very efficient in the study of $\mathrm{SnP}_{2} \mathrm{O}_{7}$ where ${ }^{31} \mathrm{P} /{ }^{31} \mathrm{P}$ correlation enabled to spectrally differentiate 49 different $\mathrm{P}_{2} \mathrm{O}_{7}$ groups (98 resolved non-equivalent $\mathrm{P}$ sites) in a $3 \times 3 \times 3$ superstructure [2]. We have shown recently that the small but significant scalar J-coupling between ${ }^{31} \mathrm{P}$ and ${ }^{27} \mathrm{Al}$ can be used to efficiently generate $\left\{{ }^{31} \mathrm{P}\right\}{ }^{27} \mathrm{Al}$ correlation using an HMQC experiment [7]. The $\left\{{ }^{31} \mathrm{P}\right\}$ ${ }^{27} \mathrm{Al} \mathrm{HMQC}$ spectrum of $\mathrm{AlPO}_{4}-40$ is shown in Figure 3, where each cross peak evidences the presence of a chemical bond between $\mathrm{Al}$ and $\mathrm{P}$ sites. This spectrum can be modeled from the isotropic positions of ${ }^{31} \mathrm{P}$ and ${ }^{27} \mathrm{Al}$ obtained from the analysis of the $1 \mathrm{D}^{31} \mathrm{P}$ and MQMAS ${ }^{27} \mathrm{Al}$ experiments but does not allow a complete resolution because of the significant second order broadening of the ${ }^{27} \mathrm{Al}$ resonances (along the horizontal axis) already observed in the $1 \mathrm{D}$ and MQMAS experiments.

The build up curves of the HMQC experiment are shown in Figure 4. Since very similar $\mathrm{T}_{2}{ }^{\prime}$ relaxation times (typically $\sim 15 \mathrm{~ms}$ ) were measured for each $\mathrm{Al}$ sites $\left(\mathrm{Al}_{\mathrm{IV}-1}, \mathrm{Al}_{\mathrm{IV}-\mathrm{II}}\right.$ and $\mathrm{Al} V \mathrm{~V}$ ) and since all the sites correspond to $\mathrm{Al}-(\mathrm{OP})_{4}$ environments, these curves directly translate into differences in the isotropic scalar $\mathrm{J}_{2}(\mathrm{Al}-\mathrm{O}-\mathrm{P})$ couplings. We already know from experiment on simpler phases [7] or from selective excitation experiments [8] that these couplings may vary significantly from one Al-O-P bond to another. This is obviously bearing valuable information on the conformation of the Al-O-P bonds; however, an analysis of the dispersion of measured scalar coupling values is beyond the scope of this paper, given our current ignorance of the ins and outs of the scalar $\mathrm{J}_{2}{ }^{27} \mathrm{Al}-\mathrm{O}-{ }^{31} \mathrm{P}$ couplings due to the very limited number of published measurements. No measurement of such a coupling has been performed in liquid state due to the rapid quadrupolar relaxation of ${ }^{27} \mathrm{Al}$ and very few recent measurements in solids have actually been reported [7,8]. However, the current progress in the calculation of J-couplings (GAUSSIAN) from structural data will provide a tool for the interpretation of our measured scalar coupling values.

It has already been shown that isotropic MQMAS resolution can be combined with INEPT in an MQ-INEPT experiment [9]. This experiment allows ultimate resolution in a 2D experiment at the cost of the loss of the anisotropic quadrupolar broadening information that is part of the characterization of the ${ }^{27} \mathrm{Al}$ sites. We designed a new $3 \mathrm{D}$ experiment that combines all the powers of the MQMAS experiment, which correlates isotropic to anisotropic ${ }^{27} \mathrm{Al}$ signatures, and provides the correlation map to adjacent ${ }^{31} \mathrm{P}$. The 3D MQMAS-HMQC pulse sequence consists in three different steps. The experiment starts with triple quantum coherence excitation of ${ }^{27} \mathrm{Al}$, followed by $\mathrm{t}_{1}$ evolution before conversion to single quantum coherence with a shifted echo evolution and full echo acquisition during $\mathrm{t}_{2}$, as proposed in the shifted echo MQMAS experiment [10]. The third dimension is obtained by implementing the HMQC scheme (Heteronuclear Multiple Quantum Correlation) with an evolution delay $t_{3}$ during the shifted-echo pulse of MQMAS-SE experiment.

The resulting spectrum is a three dimensional dataset correlating the $\left\{{ }^{27} \mathrm{Al}-3 \mathrm{Q}\right\},\left\{{ }^{31} \mathrm{P}\right\}$, and ${ }^{27} \mathrm{Al}-1 \mathrm{Q}$ observed spectrum. This dataset is sheared in the $\left\{{ }^{27} \mathrm{Al}-3 \mathrm{Q}\right\}{ }^{27} \mathrm{Al}-1 \mathrm{Q}$ plane to build the isotropic dimension and provide a spectrum as presented in Figure 6. An optimal 
signal to noise ratio is obtained by acquiring the full echo and synchronizing all the evolution times with multiple of the MAS rotation period [11].

The wealth of available data allows us to give a comprehensive interpretation of the

${ }^{31} \mathrm{P}$ and ${ }^{27} \mathrm{Al}$ spectra and discuss the number of non-equivalent sites in the structure. Our modeling of the different spectra, performed using a modified version of the "dmfit" software [13], requires at least 21 different $\mathrm{P}$ sites and 20 different $\mathrm{Al}$ sites to account for the isotropic/anisotropic dimensions of the 3D experiment, the $\left\{{ }^{31} \mathrm{P}\right\}{ }^{27} \mathrm{Al} \mathrm{HMQC}$, and the ${ }^{27} \mathrm{Al}$ MQMAS. Among the 21 resolved ${ }^{31} \mathrm{P}$ lines, 8 have multiple intensities $(6-\mathrm{x} 2,1-\mathrm{x} 3$ and 1-x4) and show more than four correlation peaks with distinct ${ }^{27} \mathrm{Al}$ resonances. We suggest that the unit cell proposed from X-Ray diffraction should at least be quadrupled and could contain 32 different $\mathrm{P}$ (and $\mathrm{Al}$ ) sites in a single phase or in an assembly of different phases.

As reported by McCusker et al. [1] from a high resolution X-Ray diffraction study, the anionic $\left[\mathrm{Al}_{32} \mathrm{P}_{32} \mathrm{O}_{128}(\mathrm{OH})_{4}\right]^{4-}$ framework of $\mathrm{AlPO}_{4}-40$ can be understood as constructed from two distinct types of clusters, each containing four crystallographically independent Al sites. One cluster contains $4 \mathrm{Al}$ and $4 \mathrm{P}$ sites plus the hydroxyl $\mathrm{O}_{33}$ site bridging two $\mathrm{Al}_{\mathrm{V}}$ sites. The second cluster only contains $\mathrm{Al}_{\mathrm{IV}}$ sites. Simple considerations do not allow the direct identification of the $\mathrm{Al}_{\text {IV-I }}$ and $\mathrm{Al}_{\text {IV-II }}$ sites. ${ }^{27} \mathrm{Al} /{ }^{27} \mathrm{Al}$ correlation experiment obtained using through space dipolar interaction [14] (Figure 7) or through bond P relayed J-coupling [15] (not shown) must be deployed. In these two experiments the only absent $\mathrm{Al} / \mathrm{Al}$ correlation is the $\mathrm{Al}_{\text {IV-II }} / \mathrm{Al}_{\text {IV-II }}$ correlation, which implies that no $\mathrm{Al}$ IV-II-O-P-O-Al $\mathrm{I}_{\text {IV-II }}$ chemical bond can be observed. An analysis of the $\mathrm{Al} / \mathrm{P}$ and $\mathrm{P} / \mathrm{Al}$ bond tables (ICSD-88919 ref. 4) reveals that only $\mathrm{Al}_{1}$ and $\mathrm{Al}_{5}$ are not connected to a common $\mathrm{P}$ site and may thus be ascribed to the $\mathrm{Al}_{\mathrm{IV}-\mathrm{II}}$ group. These sites are also the inner most sites of the framework structure.

\section{Conclusion}

In conclusion, we show that the microporous alumino-phosphate $\mathrm{AlPO}_{4}-40$ has $\mathrm{NMR}$ signatures globally compatible with the proposed X-Ray structure with a quadrupling of the unit cell. Thanks to the enhanced resolution obtained with common $2 \mathrm{D}$ experiments and a new 3D MQMAS-HMQC experiment we could measure the NMR parameters of 21 resolved ${ }^{31} \mathrm{P}$ sites and 20 resolved ${ }^{27} \mathrm{Al}$ sites, along with their respective multiplicities. Moreover, the two types of $\mathrm{Al}_{\mathrm{IV}}$, segregated by their chemical shifts and revealed by high field NMR spectra are attributed to the generic crystallographic sites $\mathrm{Al}_{1}$ and $\mathrm{Al}_{2}$ which are the only ones not connected together. The set of ${ }^{31} \mathrm{P} /{ }^{27} \mathrm{Al} 1 \mathrm{D}, 2 \mathrm{D}$ experiment along with the new 3D MQMASHMQC allow the direct analysis of binding schemes in the three dimensional building units.

\section{Acknowledgments}

We acknowledge financial support for CNRS and Région Centre; CM \& DI acknowledge fellowship support from CNRS and Le Studium.

\section{Notes and references}

1 N. Hedin, R. Graf, S.C. Christiansen, C. Gervais, R.C. Hayward, J. Eckert, B.F. Chmelka, J. Am. Chem. Soc. 2004, 124, 9425-9432; D.H. Brouwer, R.J. Darton, R.E. Morris, M.H. Levitt, J. Am. Chem. Soc. 2005; J. Dutour, N. Guillou, C. Huguenard, F. Taulelle, C. Mellot-Draznieks, G. Férey, Solid State Sciences 2004, 6, 1059-1067.

2 F. Fayon, I.J. King, R.K. Harris, R.B.K. Gover, J.S.O. Evans, D. Massiot, Chem. Mater. 2003, 15, 2234-2239

3 J.P. Lourenço, M.F. Ribeiro, F. Ramôa Ribeiro, J. Rocha, B. Onida, E. Garrone, Z. Gabelica, Zeolites, 1997, 18, 398-407; J.P. Lourenço, M.F. Ribeiro, C. Borges, J. 
Rocha, B. Onida, E. Garrone, Z. Gabelica, Microporous and Mesoporous Materials, 2000, 38, 267-278.

4 V. Ramaswamy, L.B. McCusker, C. Baerlocher, Microporous Mesoporous Materials, 1999, 31, 1-8; ICSD-88919

5 J. Rocha, J.P. Lourenço, M.F. Ribeiro, C. Fernandez, J.P. Amoureux, Zeolites, 1997, 19, 156-160; C. Fernandez, C. Morais, J. Rocha, M. Pruski Solid State NMR, 2001, 2161 70 ; C.M. Morais, C. Fernandez, V. Montouillout, F. Taulelle and J. Rocha, Stud. Sci. Surf. Catal.,2002, 142, 1915-1918. Eds. R. Aiello, G. Giordano and F. Testa, Elsevier.

6 L. Delevoye, C. Fernandez, C. M. Morais, J. P. Amoureux, V. Montouillout and J. Rocha, Solid State Nucl. Magn. Reson., 2002, 22 501-512.

7 D. Massiot, F. Fayon, B. Alonso, J. Trebosc and J.P. Amoureux, J. Magn. Reson., 2003, 164, 165-170.

8 J.P.Amoureux, J.Trebosc, J.W.Wiench, D.Massiot, M.Pruski, Solid State NMR 2005, 27, 228-232.

9 J.W. Wiench and M. Pruski, Solid State Nucl. Magn. Reson., 2004, 26, 51-55.

10 D. Massiot, B. Touzo, D. Trumeau, J.P. Coutures, J. Virlet, P. Florian and P.J. Grandinetti, Solid State Nucl. Magn. Reson., 1996, 6, 73-83.

11 D.Massiot, J. Magn. Reson. A, 1996, 122, 240.

12 V. Lacassagne, P. Florian, V. Montouillout, C. Gervais, F. Babonneau and D. Massiot, Magn. Reson. Chem., 1998, 36, 956-959.

13 D. Massiot, F. Fayon, M. Capron, I. King, S. Le Calvé, B. Alonso, J-O. Durand, B. Bujoli, Z. Gan, G. Hoatson, Magn. Reson. Chem., 2002, 40, 70-76.

14 G. Mali, F. Taulelle, Chem. Commun., 2004, 868-869; G. Mali, G. Fink, F. Taulelle J. Chem. Phys. 2004, 120, 2835-2845

15 M. Deschamps, F. Fayon, V. Montouillout, D. Massiot Chem. Commun., 2006, 19241925 


\section{Tables}

(a)

\begin{tabular}{l|l|l}
\hline & $\delta_{\mathrm{CS}}(\mathrm{ppm})$ & Multiplicity \\
\hline P 1 & -14.1 & 1 \\
P 2 & -14.7 & 2 \\
P 3 & -15.7 & 2 \\
P 4 & -16.5 & 1 \\
P 5 & -17.4 & 1 \\
P 6 & -18.2 & 1 \\
P 7 & -18.5 & 1 \\
P 8 & -19.1 & 1 \\
P 9 & -20.6 & 1 \\
P 10 & -21.1 & 1 \\
P 11 & -21.5 & 2 \\
P 12 & -22.8 & 2 \\
P 13 & -24.8 & 1 \\
P 14 & -25.2 & 3 \\
P 15 & -26.7 & 2 \\
P 16 & -27.1 & 2 \\
P 17 & -28.6 & 4 \\
P 18 & -28.9 & 1 \\
P 19 & -29.7 & 1 \\
P 20 & -30.0 & 1 \\
P 21 & -30.3 & 1 \\
\hline
\end{tabular}

(b)

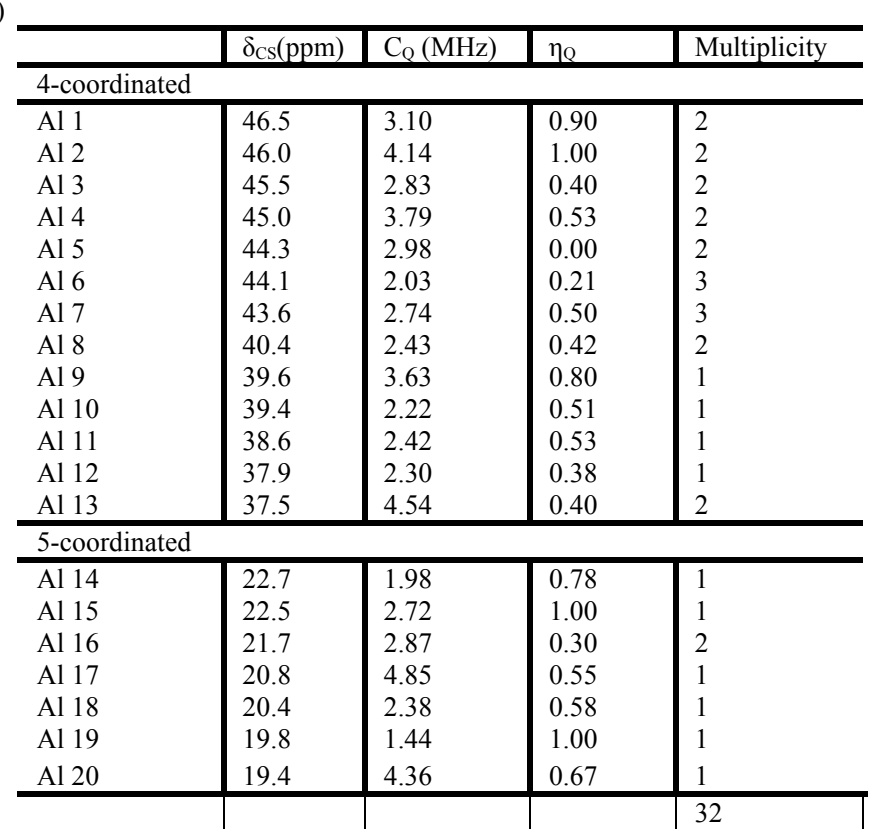

Table 1: (a) Isotropic chemical shift $\left(\delta_{\mathrm{CS}}\right)$ and relative intensities of the different phosphorous lines obtained from the simulation of the ${ }^{31} \mathrm{P}\left\{{ }^{27} \mathrm{Al}\right.$ decoupled $\}$ MAS spectrum acquired at 17.6 $\mathrm{T}\left({ }^{1} \mathrm{H}\right.$ Larmor frequency of $\left.750 \mathrm{MHz}\right)$. (b) Isotropic chemical shift $\left(\delta_{\mathrm{CS}}\right)$, quadrupolar constant $\left(\mathrm{C}_{\mathrm{Q}}\right)$ and asymmetry parameter $\left(\eta_{\mathrm{Q}}\right)$ obtained from the simulation of the ${ }^{27} \mathrm{Al}\left\{{ }^{31} \mathrm{P}\right.$ decoupled 3Q MAS spectrum recorded at 17.6 T.

\section{Figures}

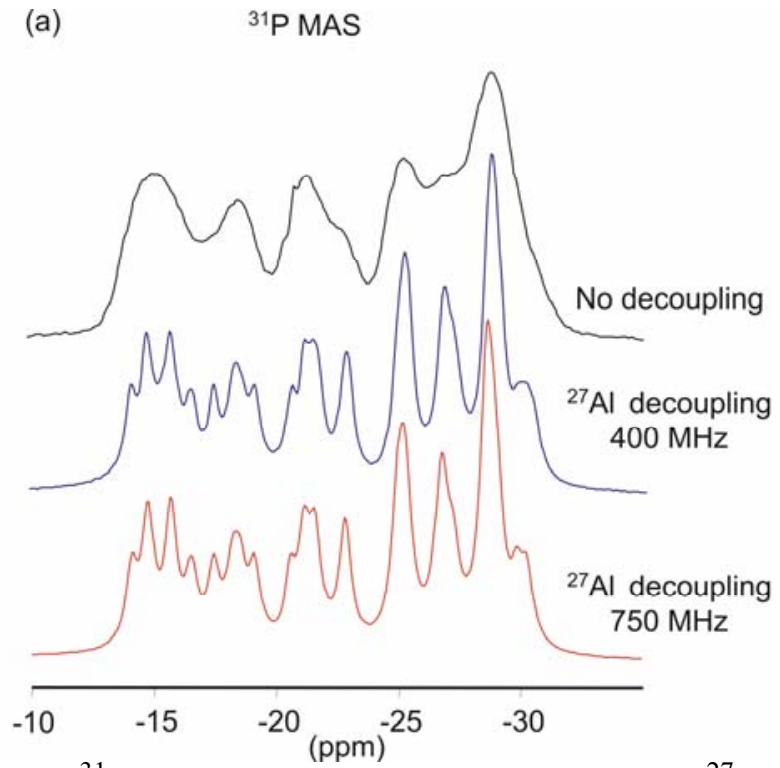

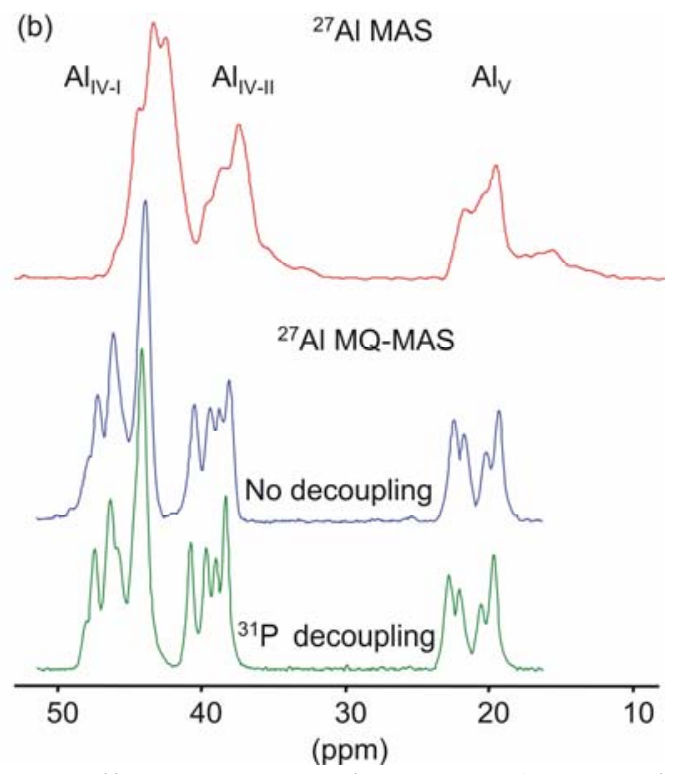

Figure $1{ }^{31} \mathrm{P}$ MAS spectra without and with ${ }^{27} \mathrm{Al}$ decoupling at 9.4 and $17.6 \mathrm{~T}$ (400 and $750 \mathrm{MHz}$ for the ${ }^{1} \mathrm{H}$ Larmor frequency). (b) ${ }^{27} \mathrm{Al}$ MAS spectrum and MQMAS isotropic projections with and without ${ }^{31} \mathrm{P}$ decoupling. 

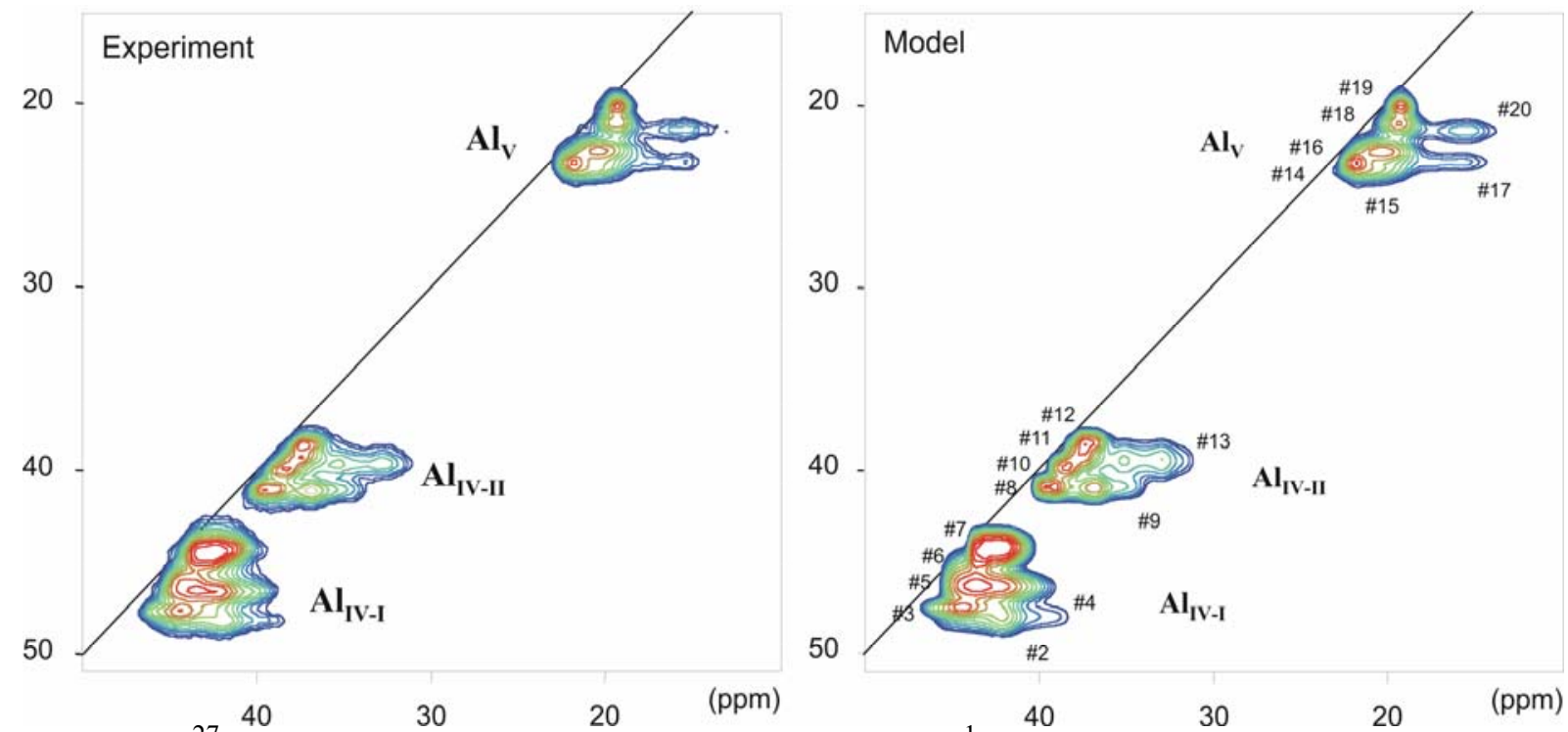

Figure $2{ }^{27} \mathrm{Al}$ MQMAS spectrum recorded at $17,6 \mathrm{~T}\left({ }^{1} \mathrm{H}\right.$ Larmor frequency at $\left.750 \mathrm{MHz}\right)$ showing complete resolution of $\mathrm{Al}_{\mathrm{IV}-\mathrm{I}}, \mathrm{Al}_{\mathrm{IV}-\mathrm{II}}$ and $\mathrm{Al}_{\mathrm{V}}$ groups of lines (a) experimental spectrum and (b) modeled spectrum with 20 different lines according to Table 1. The MAS rate was $v_{\mathrm{r}}=14 \mathrm{kHz}$ spinning rate and the recycle delay was set to $1 \mathrm{~s} .192$ points $(24$ scans per point) were acquired in the $t_{1}$ dimension, synchronously with the spinning rate $\left(t_{1}\right.$ increments of $\left.1 / v_{\mathrm{r}}\right)[11]$.
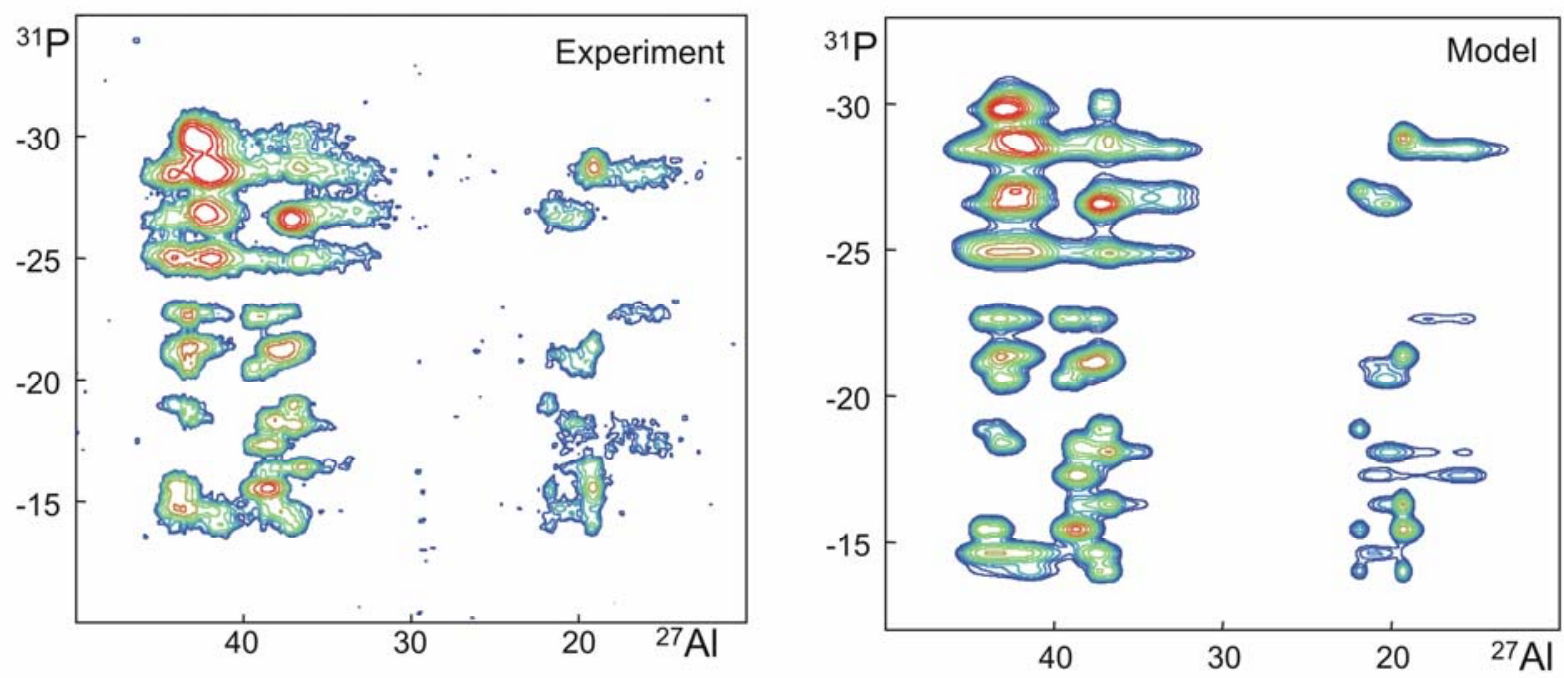

Figure 3. Left : $\left\{{ }^{31} \mathrm{P}\right\}{ }^{27} \mathrm{Al} \mathrm{HMQC}$ correlation spectrum recorded at $17.6 \mathrm{~T}(750 \mathrm{MHz})$ with a MAS rate of $v_{\mathrm{r}}=14 \mathrm{kHz}$ and a recycle delay of $1 \mathrm{~s}$. 256 points (32 scans per point) were acquired in the $t_{1}$ dimension synchronously with the spinning rate (i.e. using $t_{1}$ increments of 1/ $v_{\mathrm{r}}$ ) [7]. Right: The corresponding modeled spectrum is displayed, using the parameters shown in Table 1. 


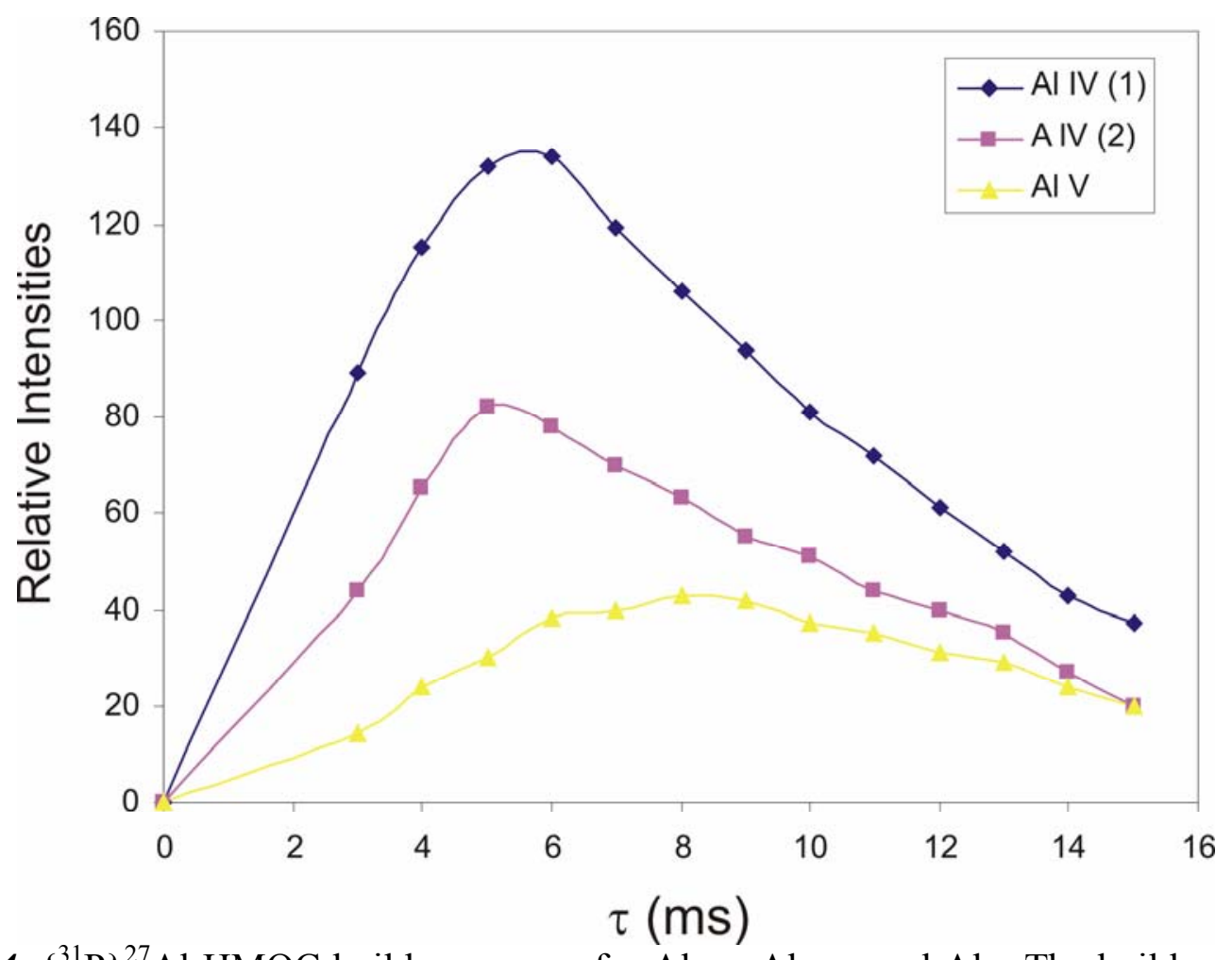

Figure 4. $\left\{{ }^{31} \mathrm{P}\right\}^{27} \mathrm{Al} \mathrm{HMQC}$ build up curves for $\mathrm{Al}_{\mathrm{IV}-\mathrm{I}}, \mathrm{Al}_{\mathrm{IV}-\mathrm{II}}$, and $\mathrm{A} \mathrm{l}_{\mathrm{V}}$. The build up for $\mathrm{Al}_{\mathrm{V}}$ component is slower, indicating weaker $\mathrm{J}_{\text {Al-O-P }}^{2}$ scalar couplings for $\mathrm{Al}_{\mathrm{V}}$ spins.
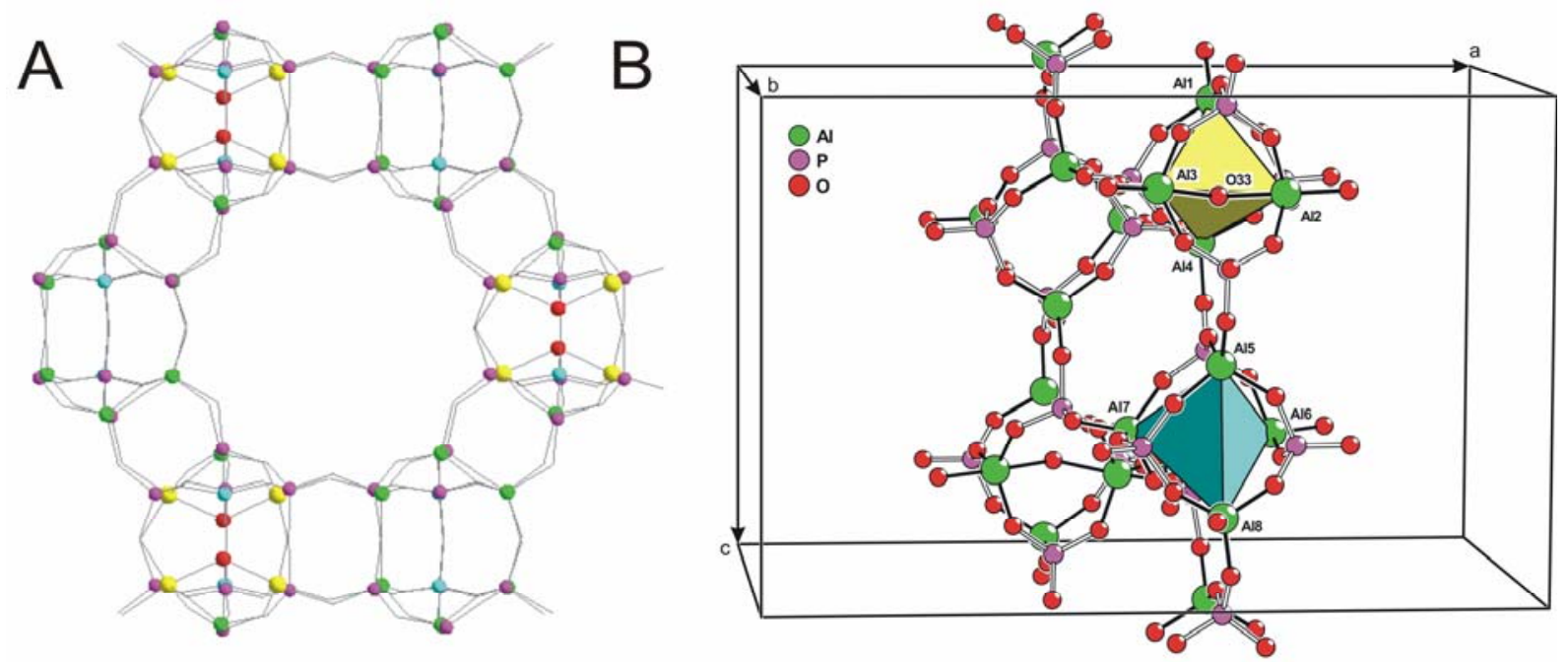

Figure 5. A. Structure (ICSD-88919) of AlPO4-40 viewed along the $c$ axis, featuring in red: $\mathrm{O}_{33}$, in purple the phosphorus atoms, in green the $\mathrm{Al}_{\mathrm{IV}-\mathrm{I}}$ atoms, in blue the $\mathrm{Al}_{\mathrm{IV} \text {-II }}\left(\mathrm{Al}_{1}\right.$ and $\left.\mathrm{Al}_{5}\right)$ and in yellow the $\mathrm{Al}_{\mathrm{V}}$ atoms, as attributed in the discussion. B. Section of the anionic $\left[\mathrm{Al}_{32} \mathrm{P}_{32} \mathrm{O}_{128}(\mathrm{OH})_{4}\right]^{4-}$ framework of $\mathrm{AlPO}_{4}-40$ viewed in perspective down the b-axis. The framework is constructed by the spatial repetition of two aluminium clusters (yellow and cyan tetrahedra). 

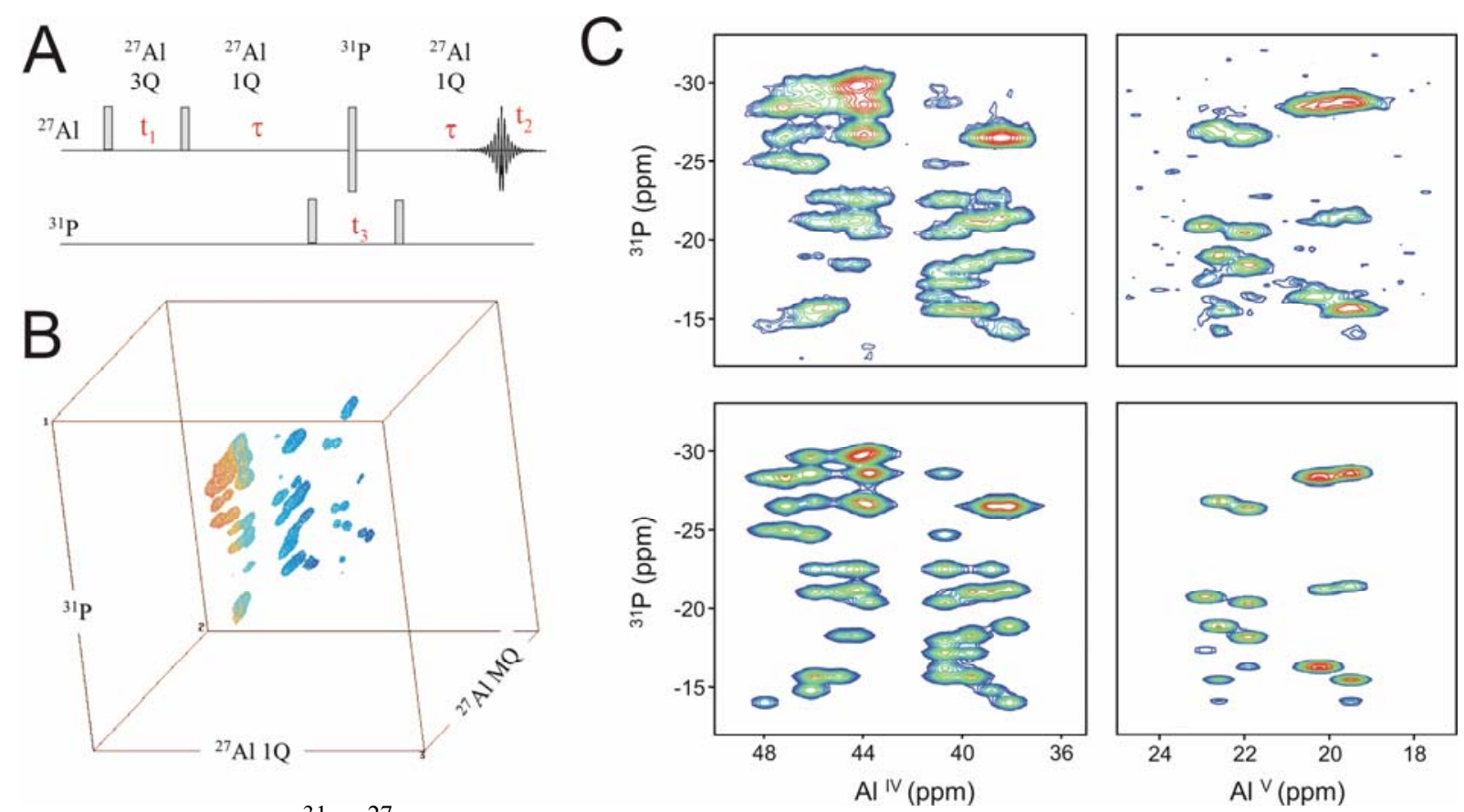

Figure 6. $3 \mathrm{D}\left\{{ }^{31} \mathrm{P}\right\}^{27} \mathrm{Al}$ MQMAS pulse sequence (A) and spectrum (B) providing isotropic/anisotropic and bonding characterization of the Al-O-P network. The spectrum was recorded at $17.6 \mathrm{~T}$ with a MAS spinning rate of $14 \mathrm{kHz}$. The $t_{2}$ increment for the indirect dimension of the ${ }^{27} \mathrm{Al}$ MQMAS was set to $2 / v_{\mathrm{r}}$ while the $\mathrm{t}_{1}$ time increment for the HMQC ${ }^{31} \mathrm{P}$ dimension was set to $1 / v_{\mathrm{r}}$. In $\mathrm{C}$, observed and modelled $\left\{{ }^{31} \mathrm{P}\right\}{ }^{27} \mathrm{Al}$ (isotropic dimension) 3D MQ-HMQC projections are displayed. The parameters used in the model are shown in Table 1.

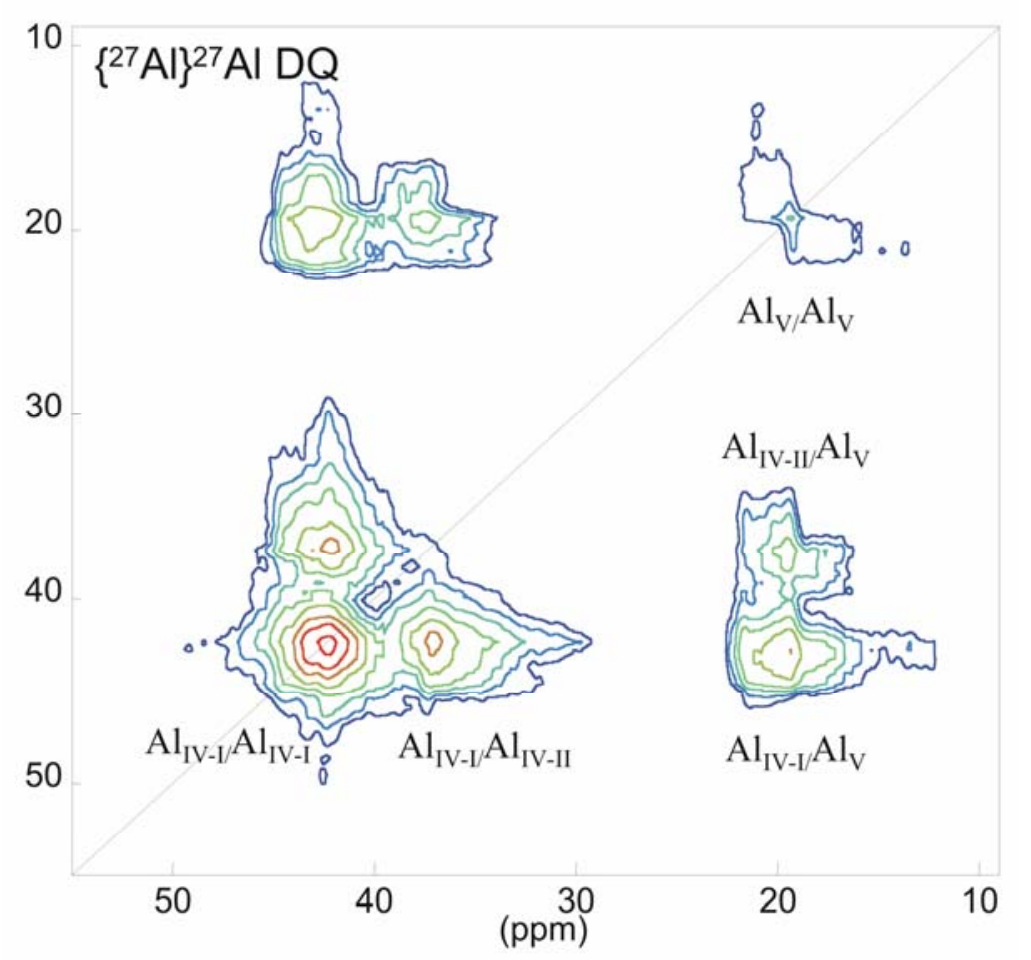

Figure 7 Double Quantum dipolar ${ }^{27} \mathrm{Al} /{ }^{27} \mathrm{Al}$ correlation spectrum featuring no intensity at the $\mathrm{Al}_{\mathrm{IV}-\mathrm{II}} / \mathrm{Al}_{\mathrm{V}}$ position 